\title{
Two new species of the dinoflagellate cyst genus Carpatella Grigorovich, 1969 from the Cretaceous-Tertiary transition in New Zealand
}

\author{
PI SUHR WILLUMSEN \\ Victoria University of Wellington, PO Box 600, Wellington, New Zealand (Current address: Institutt for Geofag, Universitetet i Oslo, \\ P.O. Box 1047, Blindern N-0316 Oslo, Norway (e-mail: pi.willumsen@geo.uio.no).
}

\begin{abstract}
A palynological study of Upper Cretaceous and Lower Paleocene sections from South Island, New Zealand, revealed the presence of two new species of Carpatella: Carpatella septata sp. nov. and Carpatella truncata sp. nov. Both species are stratigraphically important and the first occurrence of C. septata is a significant uppermost Maastrichtian event. Carpatella truncata is restricted to a narrow stratigraphical interval in the lowest Paleocene. J. Micropalaeontol. 23(2): 119-125 November 2004.
\end{abstract}

\section{INTRODUCTION}

During a palynological study of four Upper Cretaceous and Lower Paleocene sections from South Island, New Zealand, two new species of the genus Carpatella Grigorovich, $1969-$ Carpatella septata and Carpatella truncata - were recorded. The assemblages examined come from the sections Mead Stream, Branch Stream, mid-Waipara River and Grey River (Fig. 1). During the late Cretaceous and early Paleocene these four sections were located in the Canterbury Basin and East Coast Basin (Fig. 2).

The type species of the genus Carpatella - Carpatella cornuta Grigorovich, 1969 - was established as an important lowest Paleocene (basal Danian) marker in Europe by Hansen (1977, 1979a, b) and Kjellström \& Hansen (1981). They suggested that the first occurrence of $C$. cornuta marks the lowest Paleocene (Danian) strata in the Danish and Swedish part of the North Sea. Carpatella cornuta was used as the index fossil for the C. cornuta Zonule (Hansen, 1977).

The two new species described below, C. septata and C. truncate, are assigned to the genus Carpatella based on Damassa's (1988) emendation of the genus. Because the original type specimen of $C$. cornuta had disappeared, Damassa (1988) emended the species and designated a neotype. She also showed that the genus Carpatella had a paratabulation that is essentially identical to that of other dinoflagellate cysts having a Ventriosum pattern in the Aptiana-Ventriosum complex of Helenes (1984, 1986). Carpatella cornuta was also observed in the New Zealand material examined and it co-occurs with the two new species in the lowest Paleocene (Pl. 1, figs 1-2 show two different New Zealand specimens of $C$. cornuta). The two new species, Carpatella septata and $C$. truncata, have intra-tabular ornaments composed of low ridges or short processes and, thus, differ from $C$. cornuta which has its paratabulation indicated by parallel rows of pits visible under SEM (Damassa, 1988: 170).

\section{MATERIALS AND METHODS}

Rock samples used in this study were collected from the following four outcrop sections on the mainland, South Island, New Zealand: Mead Stream, Branch Stream, mid-Waipara River and Grey River (Fig. 1). The four sections span latest Maastrichtian to early Paleocene times and were investigated as a part of a high-resolution biostratigraphical and palaeoenvironmental study of the Cretaceous-Tertiary transition in
New Zealand. The author and co-workers, in a New Zealandfunded Cretaceous-Tertiary boundary project led by C. J. Hollis, undertook this study between 1998 and 2002. As a part of this project a total of 300 samples were examined for palynology by the author.

Standard palynological techniques, involving the use of hot hydrochloric acid $(\mathrm{HCl})$ followed by treatment with cold hydrofluoric acid (HF) were used. Short oxidation (max. 2-3 min.) with $36 \%$ nitric acid $\left(\mathrm{HNO}_{3}\right)$ and heavy liquid separation (sodium polytungstate) was carried out on all samples. The organic material left after the acid treatment was sieved through $6 \mu \mathrm{m}$ or $16 \mu \mathrm{m}$ filters and the residue was mounted in glycerine jelly on microscopic slides.

All type material is housed in the palynological type collection at the Institute of Geological and Nuclear Sciences (GNS), Lower Hutt, New Zealand. The illustrated specimens are either from single mounts or strew mounts and are identified with either GNS single mount number (SM number), or slide number and England Finder co-ordinates to position the specimen. The fossil locality numbers denoted by ' $\mathrm{f}$ ' and recorded in the New Zealand fossil Record File (FRF), refer to the NZMS 260 (1:50 000) Topographical Map Series. FRF sample numbers are provided for all illustrated specimens. A continuous numbering of samples processed for palynology at GNS are also provided and these are indicated by an 'L'. Specimens used in the SEM studies are from strew-mounts and were not mounted separately on stubs.

\section{SYSTEMATIC PALYNOLOGY}

Taxa mentioned below are referenced in Williams et al. (1998). The systematic classification follows Fensome et al. (1993) to subfamily level. The descriptive terminology follows Stover \& Evitt (1978), Evitt (1985) and Williams et al. (2000).

Division Dinoflagellata (Bütschli, 1885) Fensome et al., 1993 Subdivision Dinokaryota Fensome et al., 1993 Class Dinophyceae Pascher, 1914

Subclass Peridiniphycidae Fensome et al., 1993 Order Gonyaulacales Taylor, 1980

Suborder Gonyaulacineae Norris, 1978 (autonym)

Family Gonyaulacaceae Lindemann, 1928

Subfamily Cribroperidinioideae Fensome et al., 1993

Genus Carpatella Grigorovich, 1969 emend. Damassa, 1988 

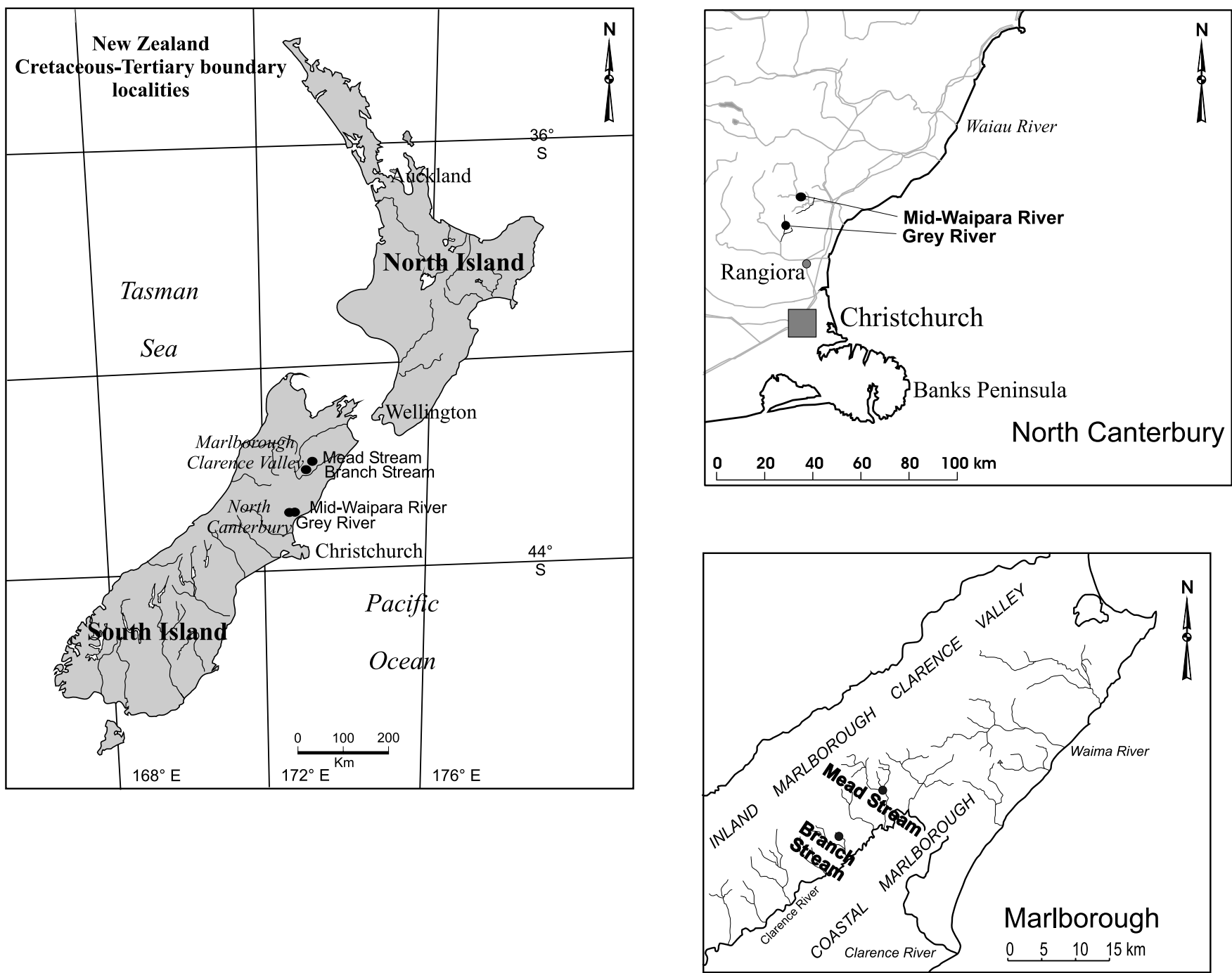

Fig. 1. Locality map of the four New Zealand Upper Cretaceous and Lower Paleocene sections examined. Localities discussed in the text are marked with a black circle (maps are modified from Hollis et al., 2000).

Carpatella septata sp. nov.

(Pl. 1, figs 3, 4; Pl. 2, figs 1-6)

1987 Danea cf. californica Wilson: 14-15, pl. 2, fig. 6.

1989 Carpatella cf. cornuta Wilson et al:: 36-37, figs 5,8.

Type species. Carpatella cornuta Grigorovich, 1969, 74-76, figs 1-6 emend. Damassa, 1988.

Derivation of name. L., septum, meaning fence, hedge, with reference to the surface ornamentation of the cyst.

Diagnosis. A species of Carpatella with a complex fibrous wall structure forming numerous penitabular septal complexes indicating the paratabulation of the cyst.

Holotype. Plate 1 (fig. 4). Mead Stream, $1.8 \mathrm{~m}$ below the Cretaceous-Tertiary boundary (KTB), FRF P30/f911, L18314, $6 \mu \mathrm{m}$, position $(\mathrm{M} 44,2)$. Holotype is lodged at the Institute of Geological and Nuclear Sciences.
Paratype 1. Plate 2 (fig. 5) Mead Stream, $5.05 \mathrm{~m}$ below the KTB, FRF P30/f955, L18314, SM 4778, position (K40,1). Paratype is lodged at the Institute of Geological and Nuclear Sciences.

Paratype 2. Plate 1 (fig. 3) Branch Stream, $-3.0 \mathrm{~m}$ below the KTB, FRF O30/f355, L19341, GNS single mount number SM 4777, position (E25,3). Paratype is lodged at the Institute of Geological and Nuclear Sciences.

Type locality \& horizon. Mead Stream section, South Island, inland Marlborough, Clarence Valley, New Zealand. Upper part of the Mead Hill Formation within the uppermost Maastrichtian (upper Haumurian) to lowest Paleocene (lower Teurian) strata. In the Mead Stream section the uppermost Maastrichtian sediments are comprised of limestone with black chert stringers, whereas the lowest Paleocene sediments comprise silicified mudstone to limestone with thin layers of dark grey clay (Strong et al., 1995; Hollis et al., 2003). 


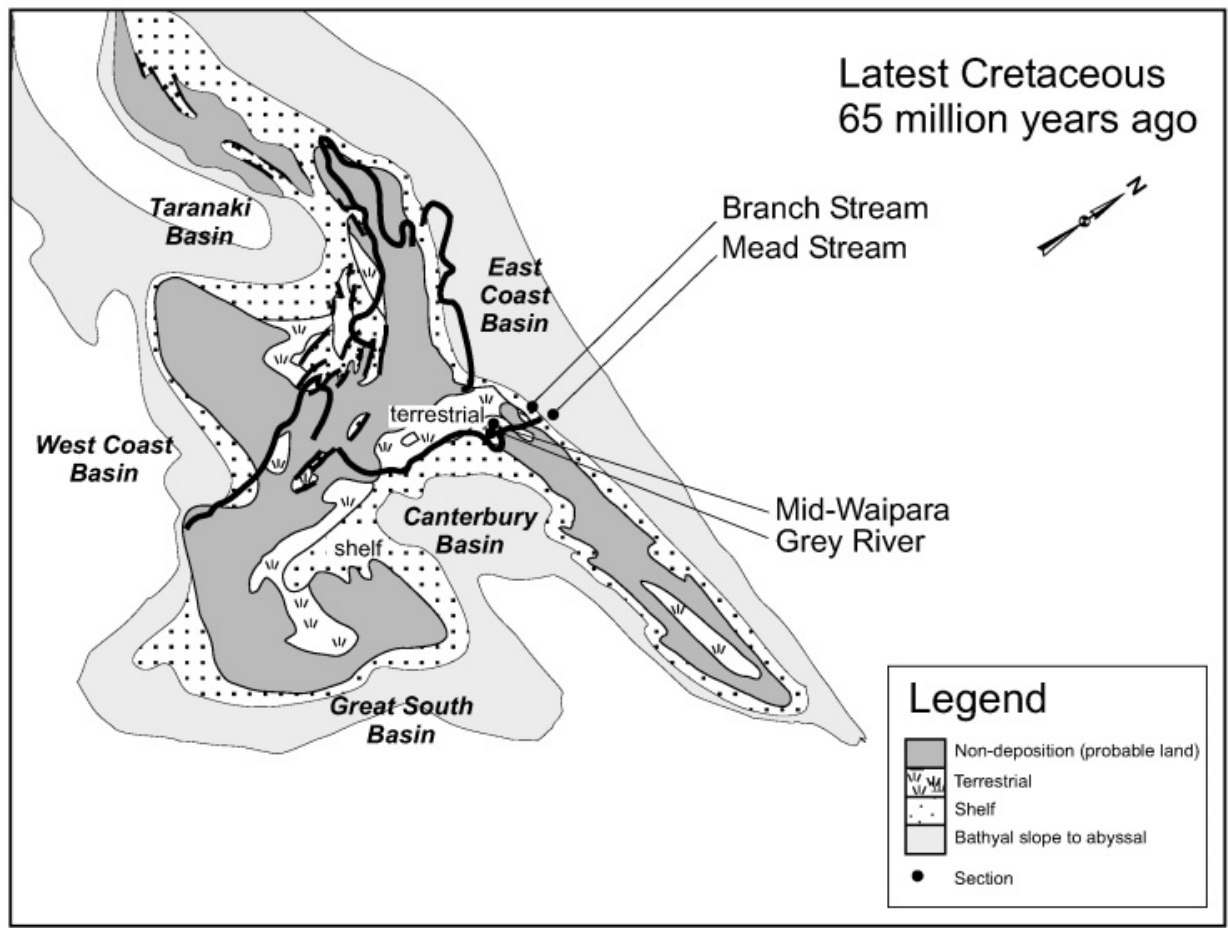

Fig. 2. Palaeogeographical reconstruction of the New Zealand region in the latest Cretaceous showing the sedimentary basins and the inferred location of the four sections: Mead Stream, Branch Stream, mid-Waipara River and Grey River (King et al., 1999). Location of the sections is indicated by black circles and follows Hollis et al. (2000).

Description. Intermediate to large subspherical to ellipsoidal proximate gonyaulacoid cyst with a single short horn at apex and antapex. The length of the apical horn is $c .13 \mu \mathrm{m}$ and the antapical horn is $c .9 \mu \mathrm{m}$ (Pl. 1, fig. 4; Pl. 2, figs 1, 2, 5, 6). The cyst is circular in polar view with a slightly more straight ventral side (Pl. 1, fig. 3). Horns are solid and the wall consists of two closely compressed layers that are structurally continuous (Pl. 2, fig. 4). The surface of the inner wall is smooth, whereas numerous solid rods, forming a complex tegillum, rise from the pedium. The irregular distribution of the rods gives the cyst a spongy perforate look. The rods are connected distally in the penitabular areas and form a $c .3-8 \mu \mathrm{m}$ high tegillum. The tegillum is developed as simulate septal complexes indicating the paratabulation of the cyst. In the cingular area a $c .5-6.5 \mu \mathrm{m}$ width perforated wing is developed (P1. 1, fig. 3 show an apical view of the cingular wing. Pl. 2, figs 1, 3-6 show mid-lateral views of the wing). The penitabular ridges indicate the sexiform gonyaulacacean tabulation and the archaeopyle is precingular, type $\mathrm{P}$, comprising paraplate 4 (3") only. Operculum is free on most specimens, but can be adherent (Pl. 1, fig. 4).

Dimensions. Holotype: total dimensions $107.5 \times 82 \mu \mathrm{m}$; length of apical horn $15.5 \mu \mathrm{m}$; length of antapical horn $10 \mu \mathrm{m}$; height of parasutural ridges $3 \mu \mathrm{m}$; width of cingular wing $6 \mu \mathrm{m}$. Paratype 1: total dimensions $102.5 \times 78.5 \mu \mathrm{m}$; length of apical horn $15 \mu \mathrm{m}$; length of antapical horn $10 \mu \mathrm{m}$; height of parasutural ridges $3 \mu \mathrm{m}$; width of cingular wing $7 \mu \mathrm{m}$. Paratype 2 : total diameter $79.5 \mu \mathrm{m}$; width of the cingular wing $6.5 \mu \mathrm{m}$. Other specimens: total dimensions $95 \times 53 \mu \mathrm{m}$; length of apical horn $13 \mu \mathrm{m}$; length of antapical horn $9 \mu \mathrm{m}$; height of parasutural ridges $4 \mu \mathrm{m}$; width of cingular wing $6.5 \mu \mathrm{m}$. Seven specimens measured.
Stratigraphical range. Carpatella septata is observed within the following intervals in the four sections examined: Mead Stream from $6.1 \mathrm{~m}$ below the KTB to $1.9 \mathrm{~m}$ above the KTB; Branch Stream from $3 \mathrm{~m}$ below the KTB to $4.4 \mathrm{~m}$ above the KTB; mid-Waipara River from $5.3 \mathrm{~m}$ below the KTB to $1.16 \mathrm{~m}$ above the KTB; Grey River from between $0.3 \mathrm{~m}$ and $0.15 \mathrm{~m}$ below the KTB.

Stratigraphical and geographical distribution. Carpatella septata has its first occurrence in uppermost Maastrichtian (uppermost Haumurian) strata within the uppermost part of the Manumiella druggii Interval Zone (Wilson, 1984, 1987; Helby et al., 1987). It has its last occurrence in the lowest Paleocene (lowest Teurian) within the lowermost part of the Trithyrodinium evittii Interval Zone (Partridge, 1976; Wilson, 1987, 1988; Wilson et al., 1989). This species occurs in a range of depositional environments (Fig. 2), from inner shelf (mid-Waipara and Grey River) to bathyal environments (Mead Stream and Branch Stream), which accentuates its importance as an uppermost Maastrichtian marker in the New Zealand region. The first occurrence of Carpatella septata is stratigraphically below the lowest Paleocene index species, C. cornuta (Willumsen, 2000, 2002; C. septata is named Carpatella sp. 1 in these publications). Carpatella cornuta has, in New Zealand, been observed in the lowest Paleocene and it has a very restricted range that is tentatively correlated to nannoplankton zone NP1 or the upper part of radiolarian zones RP1 to lower RP2 (Hollis, 1993, 1997; Hollis et al., 2000; Willumsen, 2002).

Remarks. The wall structure, paratabulation and archaeopyle are very similar in the genera Cribroperidinium and Carpatella, 

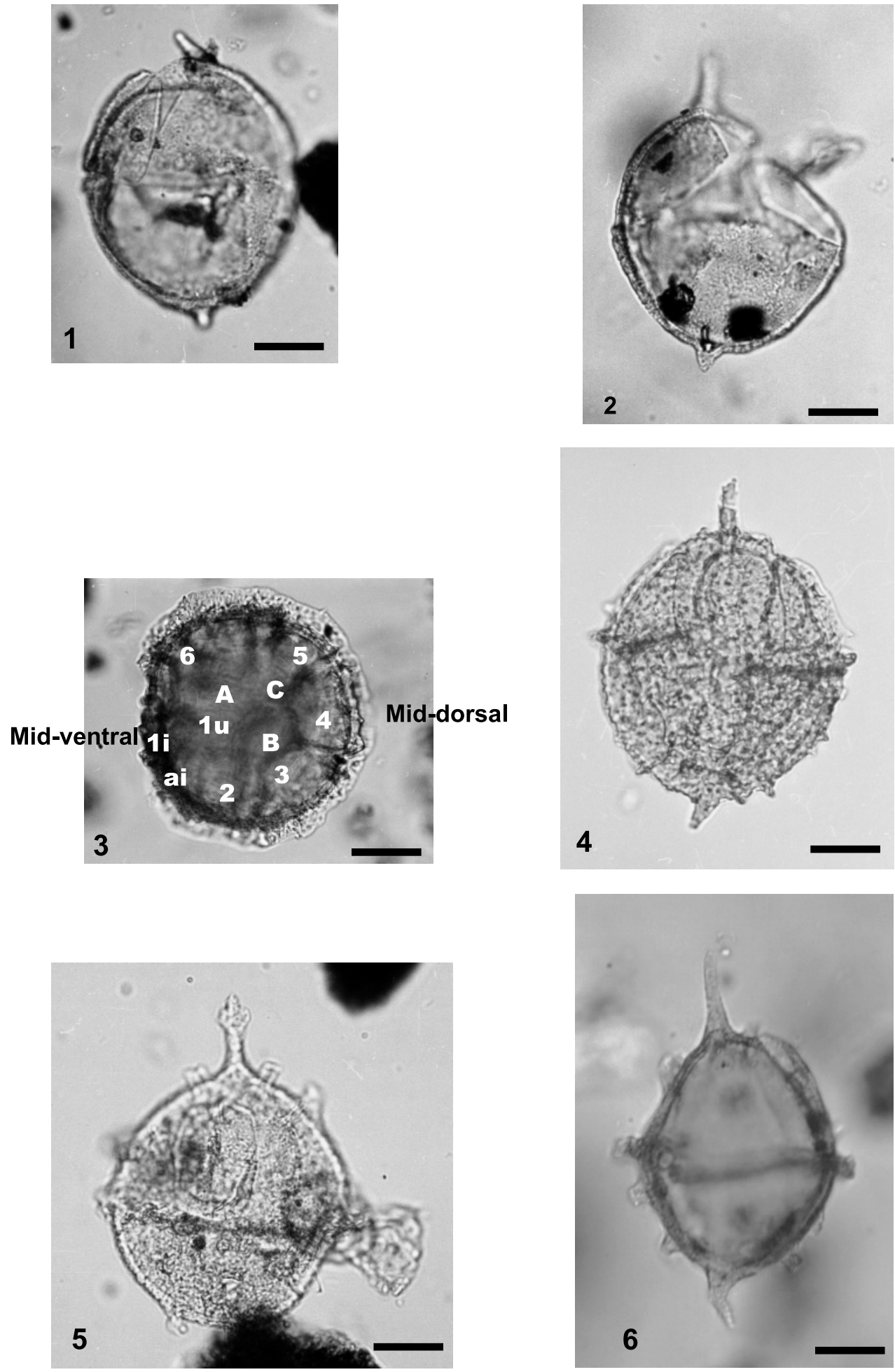

Explanation of Plate 1.

Carpatella spp.; scale bar $20 \mu \mathrm{m}$. fig. 1. Mid-lateral view of C. cornuta, mid-Waipara River, FRF M34/f560, L18469, $16 \mu \mathrm{m}, 1 / 2$ position (K41, 2). fig. 2. Mid-lateral view of C. cornuta, Grey River, M34/f523, L19150, $6 \mu \mathrm{m}$ position $(\mathrm{L} 32,2)$. fig. 3. Paratype 2 of $C$. septata in an apical view; the paratabulation is indicated; from Branch Stream, FRF O30/f355, L19341, SM 4778, position (K40, 1). fig. 4. Holotype of C. septata from a mid-dorsal view; Mead Stream, FRF P30/f911, L18314, $6 \mu \mathrm{m}, 1 / 3$ (M44, 2); note that the operculum is attached. fig. 5. Paratype 1 of $C$. truncata, mid-dorsal view; Grey River, FRF M34/f278, L18278, $16 \mu \mathrm{m}, 1 / 3$ position (E41, 1-3, D41). fig. 6. Holotype of C. truncata, Grey River, FRF M34/f523, L19150, $16 \mu \mathrm{m}, 1 / 1$ (V31, 1-3, U31). 

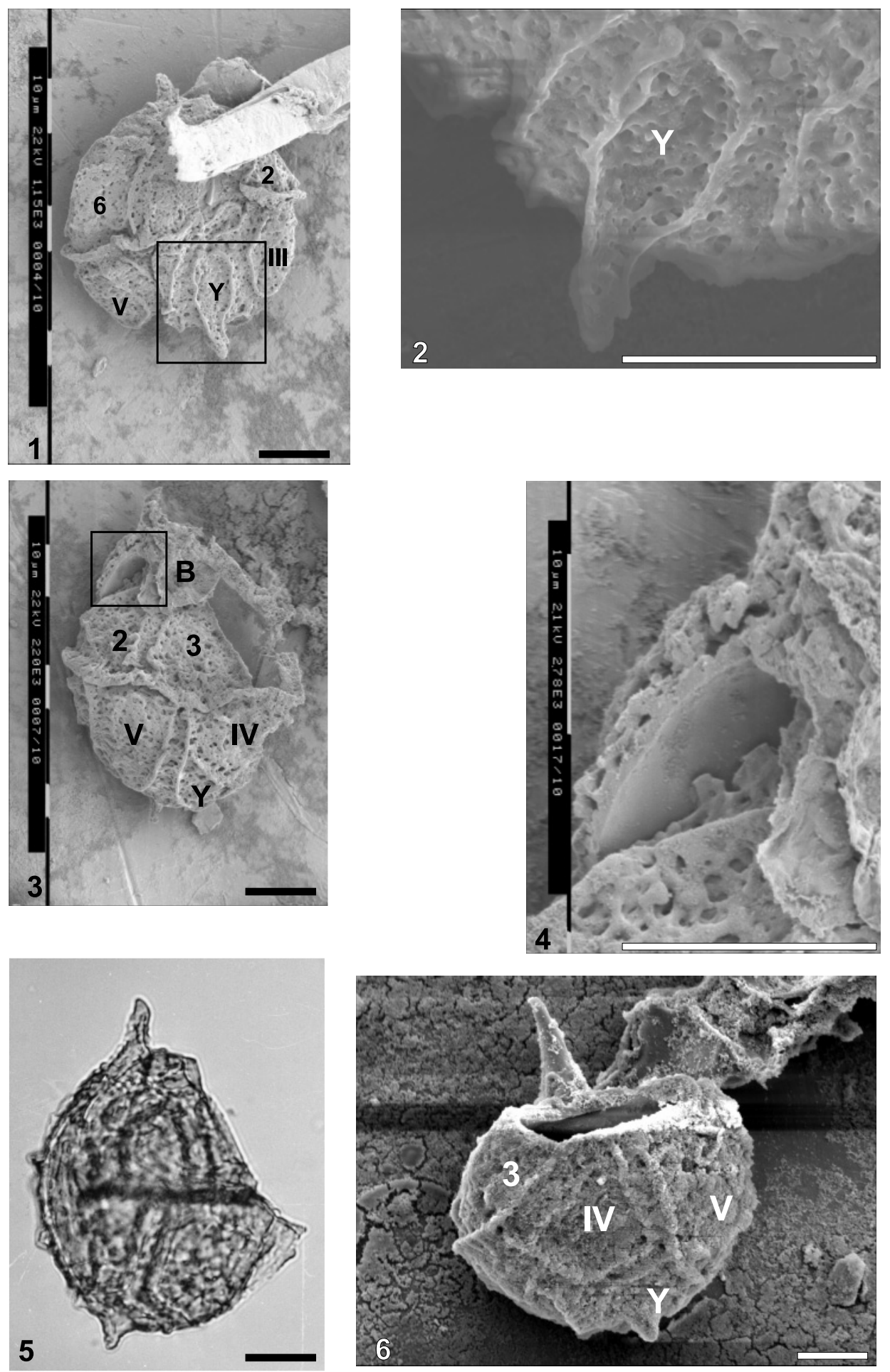

Explanation of Plate 2.

Carpatella septata sp. nov. Figs 1-4 and 6 are from a sample collected $1.8 \mathrm{~m}$ below the Cretaceous-Tertiary boundary (KTB) in the Mead Stream section. The New Zealand fossil Record number (FRF) of this sample is P30/f911 and the palynological processing number (L) is L18314. The notation of the paratabulation is indicated on some of the illustrated specimens and it follows that of Taylor (1980) and Evitt (1985). Scale bar $20 \mu \mathrm{m}$. fig. 1. Note the apical and antapical horns; mid-ventral view of the sulcus and apical paraplate Y in Carpatella septata (FRF P30/f911). fig. 2. Close-up of the apical part of Carpatella septata; same specimen as fig. 1; note the fibrous surface structure and elevated ridges indicating the paratabulation, especially the paraplate Y (FRF P30/f911). fig. 3. Mid-dorsal view of Carpatella septata; note the archaeopyle and folded wing in the cingular area (FRF P30/f911). fig. 4. Close-up of the wall structure of $C$. septata; same specimen as fig. 3; note the contact between the pre-cingular plate and the apical plate showing the smooth inner surface of the wall; the inner wall is closely compressed to the outer fibrous wall layer. fig. 5. Normal light microscopy photo of paratype 1 of $C$. septata; mid-dorsal view; focus on the peni-tabular ridges and paraplate boundaries between plate IV and II; Mead Stream, $1.8 \mathrm{~m}$ below the Cretaceous-Tertiary boundary, FRF P30/f955, L18739, SM 4777, position (E25,3). fig. 6. A mid-dorsal view of the antapical to mid-dorsal part of C. septata (FRF P30/f911). 
but the two genera can be distinguished by the presence/absence of an antapical horn (Damassa, 1988). Carpatella septata has two horns and it is, on the basis of this diagnostic feature, assigned to the genus Carpatella. The wall structure of $C$. septata is similar to species of Cribroperidinium that have the paratabulation expressed as parasutural and intratabular ridges. The type species of Carpatella - C. cornuta - has the paratabulation indicated by parasutural furrows and broader raised bands (Stover \& Evitt, 1978; Damassa, 1988) and on the larger paraplates small 'pits' ornament the intra-tabular areas. Carpatella septata differs from Carpatella cornuta Grigorovich, 1969, Carpatella sinensis He Chengquan, 1984, Carpatella humera, Carpatella circularis, Carpatella scabrata, Carpatella lamprota He Chengquan, 1991 and C. truncata sp. nov. by having a large irregular 'woven' reticulate surface ornamentation that forms distinct intratabular ridges indicating the paratabulation of the cyst. The specimen assigned by Wilson (1987) to Danea cf. californica is here placed in the new species $C$. septata. Wilson (1987) notes that $D$. cf. californica (now $C$. septata) has its first occurrence $c .3 \mathrm{~m}$ below the KTB where it is associated with Manumiella druggii. Another specimen identified by Wilson (in Wilson et al., 1989) as Carpatella cf. cornuta is also assigned to C. septata. This species was reported by Wilson et al. (1989) to have its first occurrence below the KTB.

Genus Carpatella Grigorovich, 1969 emend. Damassa, 1988 Carpatella truncata sp. nov. (P1. 1, figs 5, 6)

Type species. Carpatella cornuta Grigorovich, 1969, 74-76, figs 1-6, emend. Damassa, 1988.

Derivation of name. L., truncus, meaning cut-off, truncate, with reference to the short intra-tabular processes on the cyst.

Diagnosis. A species in the genus Carpatella with short, truncate, intra-tabular processes and a cingulum marked by a raised band.

Holotype. Plate 1 (fig. 6) Grey River section, $0.7 \mathrm{~m}$ above the KTB, FRF M34/f523, L19150, $16 \mu \mathrm{m}$, position (V31, 1-3, U31). The holotype is lodged at the Institute of Geological and Nuclear Sciences.

Paratype. Plate 1 (fig. 5) Grey River section, $0.3 \mathrm{~m}$ above the KTB, FRF M34/f278, L18278, $16 \mu \mathrm{m}$, position (E41, 1-3, D41). Paratype is lodged at the Institute of Geological and Nuclear Sciences.

Type locality \& horizon. Grey River section, North Canterbury, South Island, New Zealand. Carpatella truncata occurs in an interval between $0.01 \mathrm{~m}$ to $0.7 \mathrm{~m}$ above the $\mathrm{KTB}$ within the lower part of the Loburn Formation. The Loburn Formation is a glauconitic siltstone (Field \& Odin, 1981).

Description. Subspherical to ellipsoidal proximate gonyaulacoid cyst, single horn at apex and antapex (Pl. 1, figs 5, 6). Solid fibrous horns and an autophragm composed of two closely compressed spongy layers. From each paraplate a short fibrous process rises (maximal height $c .7 \mu \mathrm{m}$ ), indicating the paratabulation. Processes are straight, fibrous, slightly angular and truncate in the distal part. An elevated fibrous ridge with a width of c. $3 \mu \mathrm{m}$ and a thickness of $6 \mu \mathrm{m}$ marks the cingulum (Pl. 1, fig. 6). Precingular archaeopyle, type $\mathrm{P}$, consists of paraplate 4 (3") only. The archaeopyle is hoof-shaped and the operculum is mostly free.

Dimensions. Holotype: total dimensions $109.5 \times 72 \mu \mathrm{m}$; length apical horn $15 \mu \mathrm{m}$; length antapical horn $13 \mu \mathrm{m}$; height of processes $9 \mu \mathrm{m}$. Other specimens: total dimensions $95 \times 70 \mu \mathrm{m}$; length apical horn $20 \mu \mathrm{m}$; length antapical horn $13 \mu \mathrm{m}$; height of processes $8 \mu \mathrm{m}$. Ten specimens measured.

Stratigraphical range. Lowest Paleocene (lowest Teurian) within the lowermost part of the Trithyrodinium evittii Interval Zone (Willumsen, 2002, named Carpatella sp. 2 in text and figs). Carpatella truncata is very rare in all samples studied except in sample FRF M34/f523 from Grey River.

Stratigraphical and geographical distribution. This species was observed in Grey River, mid-Waipara River and Branch Stream sections. In the mid-Waipara River section, $C$. cornuta, $C$. septata and $C$. truncata co-occur in a sample $0.005 \mathrm{~m}$ above the KTB (FRF M34/f560, L18469).

Remarks. Carpatella truncata differs from Carpatella cornuta Grigorovich, 1969, Carpatella sinensis He Chengquan, 1984, Carpatella humera, Carpatella circularis, Carpatella scabrata, Carpatella lamprota He Chengquan, 1991 and C. septata sp. nov. by having short intratabular truncate processes.

\section{SUMMARY}

The development of penitabular septa and intratabular processes characterize the two new species $C$. septata and C. truncata. These features are normally observed in Cribroperidinium. The circumscription of the genus Cribroperidinium by Helenes (1984) has similarities with the two new species described herein, but $C$. septata and $C$. truncata differ from Cribroperidinium by having an apical and antapical horn, as in the genus Carpatella (Grigorovich, 1969; Damassa, 1988).

Carpatella septata and $C$. truncata are important uppermost Maastrichtian (uppermost Haumurian) to lowest Paleocene (lowest Teurian) stratigraphical markers in the two eastern New Zealand basins, East Coast and Canterbury (Willumsen, 2002). The first occurrence of C. septata is useful when the top of the Manumiella druggii Interval Zone (Wilson, 1984, 1987; Wilson et al., 1989) has to be located. The stratigraphical range of C. truncata still needs to be fully investigated, but it has so far only been recorded from the lowest Paleocene. It is rare compared with $C$. septata. Carpatella septata and $C$. truncata co-occur with $C$. cornuta in the lowest Paleocene and this interval has been indirectly correlated to nannoplankton zone NP1 via Hollis' $(1993,1997)$ radiolarian zonation (Willumsen, 2002; Hollis et al., 2003).

\section{ACKNOWLEDGEMENTS}

This study was funded by the New Zealand Marsden Fund and Danish Research Agency, Ministry of Science, Denmark. 
Graeme Wilson at the Institute of Geological and Nuclear Sciences (GNS) is thanked for suggestions to this manuscript and for his encouragement. Roger Tremain (GNS) is thanked for processing most of the samples. The author's supervisors, Mike Hannah (Victoria University of Wellington), Chris Hollis (GNS) and Poul Schiøler (Geological Survey of Greenland and Denmark), are also thanked for their help and support throughout this study.

\section{Manuscript received 28 April 2003 Manuscript accepted 30 January 2004}

\section{REFERENCES}

Damassa, S.P. 1988. Carpatella cornuta Grigorovich 1969 (Dinophyceae) - a member of the Aptiana-Ventriosum complex. Palynology, 12: 167-177.

Evitt, W.R. 1985. Sporopollenin dinoflagellate cysts: their morphology and interpretation. American Association of Stratigraphic Palynologists Foundation, Dallas, $333 \mathrm{pp}$.

Fensome, R.A., Taylor, F.J.R., Norris, G., Sarjeant, W.A.S., Wharton, D.I. \& Williams, G.L. 1993. A classification of living and fossi dinoflagellates. Micropaleontology Special Publication, 7. American Museum of Natural History, $351 \mathrm{pp}$.

Field, B.D. \& Odin, G.S. 1981. K-Ar dating of Paleocene glaucony from North Canterbury, New Zealand. New Zealand Geological Science Report, G45: 1-22.

Grigorovich, A.S. 1969. A new genus Carpatella (Dinoflagellata) from Danian-Paleocene deposits of Carpathians. Paleontologicheskii Gbornik, 6: 74-75 [In Russian].

Hansen, J.M. 1977. Dinoflagellate stratigraphy and echinoid distribution in Upper Maastrichtian and Danian deposits from Denmark. Bulletin of the Geological Society of Denmark, 26: 1-26.

Hansen, J.M. 1979a. A new dinoflagellate zone at the Maastrichtian/ Danian boundary in Denmark. Danmarks Geologiske Undersogelse Arbog: 131-140.

Hansen, J.M. 1979b. Dinoflagellate zonation around the boundary. In: Birkelund, T. \& Bromley, R.G. (Eds), Cretaceous-Tertiary boundary events, symposium I, The Maastrichtian and Danian of Denmark. University of Copenhagen, 136-142.

He Chengquan 1984. Some new genera of Late Cretaceous to Eocene microphytoplankton from western Tarim Basin in southern Zinjiang. Acta Palaeontologica Sinica, 23(6): 768-774 [In Chinese and English].

He Chengquan 1991. Late Cretaceous-Early Tertiary microphytoplankton from the western Tarim Basin in southern Xinjiang, China. Najing Institute of Geology and Palaeontology, Academia Sinica, $235 \mathrm{pp}$ [In Chinese with English summary].

Helby, R., Morgan, R. \& Partridge, A.D. 1987. A palynological zonation of the Australian Mesozoic. In: Jell, P.A. (Ed.), Studies in Australian Mesozoic Palynology. Memoir Association Australasian Palaeontologists, 4: 1-94.

Helenes, J. 1984. Morphological analysis of Mesozoic-Cenozoic Cribroperidinium (Dinophyceae), and taxonomic implications. Palynology, 8: 107-137.

Helenes, J. 1986. Some variations in the paratabulation of gonyaulacoid dinoflagellates. Palynology, 10: 73-110.
Hollis, C.J. 1993. Latest Cretaceous to Late Paleocene radiolarian biostratigraphy: A new zonation from the New Zealand region. Marine Micropaleontology, 21: 295-327.

Hollis, C.J. 1997. Cretaceous-Paleocene radiolaria from eastern Marlborough, New Zealand. Institute of Geological \& Nuclear Sciences monograph, 17. Institute of Geological \& Nuclear Sciences Limited, Lower Hutt, New Zealand, 152 pp.

Hollis, C.J., Field, B.D., Rodgers, K.A.B., Rogers, K.M., Strong, C.P. \& Willumsen, P.S. 2000. Radiolarian faunal changes across the $\mathrm{K} / \mathrm{T}$ boundary in a southern high latitude neritic-bathyal transect: an integrated approach. Poster presentation at INTERRAD 2000, ninth meeting of the International Association of Radiolarian Paleontologists, Reno-Blairsden, September 17-22.

Hollis, C.J., Rodgers, K.A., Strong, C.P., Field, B.D. \& Rogers, K.M. 2003. Paleoenvironmental changes through the Cretaceous-Tertiary transition in northern Clarence Valley, New Zealand. New Zealand Journal of Geology and Geophysics, 46: 209-234.

King, P.R., Naish, T.R., Browne, G.H., Field, B.D. \& Edbrooke, S.W. (compilers) 1999. Cretaceous to Recent Sedimentary Patterns in New Zealand. Institute of Geological and Nuclear Sciences folio Series, 1: $23 \mathrm{pp}$.

Kjellström, G. \& Hansen, M. 1981. Dinoflagellate biostratigraphy of the Cretaceous-Tertiary boundary in southern Scandinavia. Geologiska Föreningens $i$ Stockholm Förhandlingar, 103: 271-278.

Partridge, A.D. 1976. The Geological Expression of Eustasy in the Early Tertiary of the Gippsland Basin. APEA Journal, 16: 73-79.

Stover, L.E. \& Evitt, W.R. 1978. Analyses of Pre-Pleistocene Organicwalled Dinoflagellates. Stanford University Publications, Geological Sciences, 15: $300 \mathrm{pp}$.

Taylor, F.J.R. 1980. On dinoflagellate evolution. Biosystems, 13: 65-108.

Williams, G.L., Lentin, K.L. \& Fensome, R.A. 1998. The Lentin and Williams index of Fossil Dinoflagellates 1998 edition, 34. American Association of Stratigraphic Palynologists Foundation, 817 pp.

Williams, G.L., Lentin, K.L., Fensome, R.A., Miller, M.A. \& Sarjeant, W.A.S. 2000. A glossary of the terminology applied to dinoflagellates acritarchs and prasinophytes, with emphasis on fossils (3rd edn), 37. American Association of Stratigraphic Palynologists Foundation, $279 \mathrm{pp}$.

Willumsen, P.S. 2000. Late Cretaceous to early Paleocene palynological changes in midlatitude Southern Hemisphere, New Zealand. In: Schmitz, B., Sundquist, B. \& Andreasson, F.P. (Eds), Early Paleogene warm climates and biosphere dynamic. Geologiska Föreningens i Stockholm Förhandlingar, 122: 180-181.

Willumsen, P. S. 2002. Marine palynology across the CretaceousTertiary boundary in New Zealand. Abstract and poster presented at the Joint Meeting of AASP-TMS-NAMS, University College of London, 11-13 September.

Wilson, G.J. 1984. New Zealand Late Jurassic to Eocene dinoflagellate biostratigraphy - a summary. Newsletters on Stratigraphy, 13: $104-117$.

Wilson, G.J. 1987. Dinoflagellate biostratigraphy of the CretaceousTertiary boundary, mid-Waipara River Section, North Canterbury, New Zealand. New Zealand Geological Survey Record, 20: 8-16.

Wilson, G.J. 1988. Paleocene and Eocene Dinoflagellate Cysts from Waipawa, Hawkes Bay, New Zealand. New Zealand Geological Survey Paleontological Bulletin, 57: 1-96.

Wilson, G.J., Morgans, H.E.G. \& Moore, P.R. 1989. CretaceousTertiary boundary at Tawanui, southern Hawkes Bay, New Zealand. New Zealand Geological Survey Record, 40: 29-40. 